\title{
воок Integrated music education: Challenges of teaching and teacher training
}

Cslovjecsek, M., \& Zulauf, M. (2018)

Bern: Peter Lang. 418 pages.

ISBN-10: 3034303882

Received: 08/09/2020 | Reviewed: 10/09/2020 | Accepted: 10/09/2020

\section{Karen LUDKE}

Edge Hill University, UK

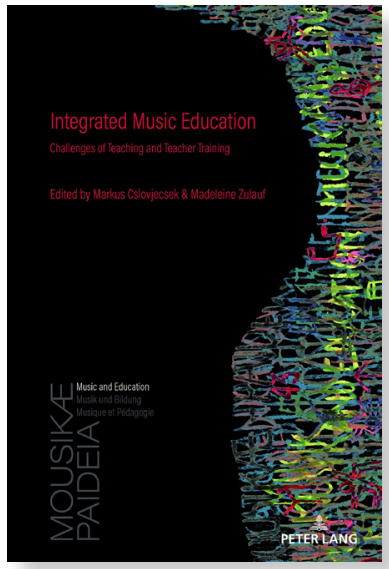

Karen.Ludke@edgehill.ac.uk

There is growing acknowledgment tives, providing clearer definitions of key conof the long-term academic and cognitive, socepts as well as practical suggestions to improve cio-cultural and economic, and physical and understanding and advance the field. The book mental health benefits that can arise from active engagement in the arts. Nevertheless, music and the arts are still among the first subjects that schools cut so they can balance their budgets, especially during a politico-cultural swing towards a «back-to-basics» education that focuses on «core» academic subjects. Against this challenge, educators and researchers have long tried to keep the creative arts in the curriculum, for example through initiatives such as STEAM, which aims to teach concepts in science, technology, engineering and mathematics through integrated arts and creative problem-solving activities.

The scope of this thought-provoking edited collection goes beyond typical initiaarose out of Markus Cslovjecsek's 2006 launch of Practice and Research in Integrated Music Education (PRIME) - now a special interest group and part of the International Society for Music Education (ISME) - which has held several conferences, symposia, and other events. Co-edited by expert researcher-pedagogues Markus Cslovjecsek and Madeleine Zulauf, they and the contributors within this volume have extensive experience in an interdisciplinary range of subject areas including music, education and teacher training. Drawing on a wide range of philosophical, theoretical and practical perspectives, one valuable goal of this volume is to help educators to better appreciate and apply some of the far-reaching benefits of integrating 
creative musical activities into their «normal» classroom's learning and teaching practices. As a result, the text is bound to appeal to teachers, teacher-trainers and researchers who are interested in keeping arts and music education alive - both for its own sake and because of the common learning processes that can lead to applied benefits in other domains.

The book itself takes a process approach, with a Starting Point that then develops through five steps:

Step 1: Approaching Integrated Music Education by Exploring Distant Horizons

Step 2: Encountering Integrated Music Education: Where School Meets Life

Step 3: Uncovering School Models in Integrated Music Education

Step 4: Becoming Familiar With Integrated Music Education Activities in the Classroom

Step 5: Being Invited Into The Minds of People Engaged in Integrated Music Education

Each «step» or section begins with a short introduction from the co-editors, providing useful background information about the perspectives and processes taken, and some of the key questions explored by or arising from the authors' contributions in each chapter. The book then concludes with Lessons Taken From the Journey: Where Next? where the co-editors explore new questions and offer suggestions of important questions that the field of integrated music education might explore in future.

In my view, three chapters in particular stand out against the overall high standard set by the volume as a whole. This list was challenging to whittle down due to the many thought-provoking ideas and perspectives put forward in each chapter.

Chapter 7 was of particular interest to me, given its focus on adolescents' French-language learning through music and the visual arts. Anne Lowe and Monique Richard describe the outcomes of an interdisciplinary music/arts/French language intervention-collaboration for students in a francophone minority community in New Brunswick, Canada. The intervention's rationale, as explained by the authors following Deveau and colleagues (2005), was partly based on the fact that «artistic education satisfies students' need for autonomy, competence, and relatedness by allowing self-assertion, exposure to new ideas, the development of tolerance, and a sense of belonging to a culture. This not only contributes to the enculturating experience but also to the empowering experience» (p. 160). The project involved the creation of new musical or visual artworks that required the students to use French (e.g., when researching to discover more about the local francophone artist they had chosen) and formed part of the learners' evaluations in French-language, music and visual arts. This chapter provides evidence for the linguistic, artistic and cultural benefits that can arise from taking part in an interdisciplinary project, even within the confines of a «typical» school and even led to visits with francophone 
artists in the region. The authors conclude, in part, that «the teaching strategies employed by the teachers revealed that a pedagogy of discovery and personal creation centred on the student can contribute to the success of a music/arts/language interdisciplinary project» (p. 165) and highlight the importance of communication and collaboration and subject-specialist teachers' (and learners') willingness to try new teaching and learning approaches and activities.

In chapter 9, Dagmar Widorski's contribution is both philosophically and pedagogically useful, focusing first on why school is organised into academic 'disciplines' and then describing how working outside of or across those disciplinary boundaries can provide students with educational experiences that can enhance and deepen literacy, rational judgment and aesthetic experiences. Sections 4 and 5 may be of particular interest to educators, with a list on page 207 of how interdisciplinary education can enhance learning through considering how these approaches can be applied to their own teaching, and then provides a concrete example - an «aural pictures» activity (Wermke, 2011) to illustrate the manner in which classroom activities can be organised.

Chapter 14 (and indeed the other contributions in Step 4) may be of particular interest to educators. The practical, didactic focus has become yet more prominent, and authors Anke Böttcher, Frits Evelein and Diana Harris describe step-by-step activity ideas that, through cooperative, social learning activities, can lead to self-determination (Deci
\& Ryan, 2000), by engaging learners in three rather different, but all embodied, structured yet creative activities in which each individual has an important role to play, within a more teacher-directed framework. With echoes from previous chapters in the volume (such as Jonathan Barnes' observation that music may have pre-dated language), the authors of chapter 14 believe that we are all inherently musical and that our musical skills and understandings can help us reflect on and express ourselves, support our wellbeing and social development - particularly when we make music together, with the feelings of belonging that this can engender.

And as Zulauf \& Cslovjecsek conclude in Chapter 2, quoting Russell and Zembylas' (2007) valuable suggestion to move away from old conceptions of integrated music (and arts) education:

«if we stop thinking in dualisms and
move beyond the either (disciplines) /
or (handmaidens) dichotomy, we may
begin to examine arts integration on
a totally different level of thinking -
that is, as multi-layered and symbiotic
with other learning» (2007, p. 288).
«To stop thinking in dichotomies is,
in our view, the major process that will
enable us to achieve a better result:
optimising the integration of music
and therefore improving the quality
of students' education.» (p. 62)

Overall, Integrated music education makes an important contribution to this emerging field - both in terms of theory and practice to help educators and researchers reflect on and promote the possibilities of integrated learning in 
and through music within varied $21^{\text {st }}$ century school systems - and the book's publication is one that all contributors can feel proud of having achieved.

\section{References}

Cslovjecsek, C., \& Zulauf, M. (2018). Integrated music education: Challenges of teaching and teacher training. Bern: Peter Lang.

Deci, E. L., \& Ryan, R. M. (2000). Self-determination theory and the facilitation of intrinsic motivation, social development, and well- being. American Psychologist, 55(1), 68-78. Retrieved from https:// selfdeterminationtheory.org/SDT/documents/2000 RyanDeci SDT.pdf
Deveau, K., Landry, R., \& Allard, R. (2005). Au-delà de l'autodéfinition: composantes distinctes de l'identité ethnolinguistique. Francophonies d'Amérique, 20, 79-93.

Russell, J., \& Zembylas, M. (2007). Arts integration in the curriculum: A review of research and implications for teaching and learning. In L. Bresler (Ed.), International handbook of research in arts education (pp. 287-312). Dordrecht, The Netherlands: Springer. doi: https://doi. org/10.1007/978-1-4020-3052-9 18

Wermke, J. (2011). Hör-Bilder: Zur Funktion von Bildern im Rah- men einer Hörerziehung. In J. Bilstein (Ed.), Anthropologie und Pädagogik der Sinne (pp. 293-317). Opladen, Germany: Barbara Budrich. 